\title{
A CONE-LIKE CECIDOMYIID GALL ON BIGELOVIA.
}

\author{
BY C. H. TYLER TOWNSEND, LAS CRUCES, N. MEX.
}

A cone-like cecidomyiid gall was found on Bigelovia graveolens, near Gallo Spring, N. M., June 21, I892. They were also found west of Apache Spring and the Rio Apache, June 22. One of the latter, opened on that date, revealed three small larvae which were apparently cecidomyiidan. Both the above localities are in western Socorro County, New Mexico. This cecidomyiid may be known as Cecidomyia bigeloviae-strobiloides.

Gall.-Length, 8 to $10 \mathrm{~mm}$.; width 3 to $6 \mathrm{~mm}$. Rather elongate, subcylindrical in general form, but little narrower on apical than on basal portion. Borne on side of twig, to which it is attached by a short and narrow stem. Rather compact, formed of many narrowed overlapping stipules, but these are apparently united and grown together, forming a compact body, only the terminal elongate portions of the outer stipules free and showing as curled tips on the outside of the gall. The stipules arranged like the cone of a pine tree, all extending nearly upward but slightly outward from the central longitudinal cell. Outside of gall covered with a thin white woolly pubescence, the gall greenish beneath this, and the rather long narrow more or less curled free terminal ends of stipules protruding through the woolliness, and growing more numerous toward tip of gall. The central cell is from 4 to $5 \mathrm{~mm}$. long, I $\mathrm{mm}$. wide, quite cylindrical, its walls a little hardened in texture. It does not extend to base of gall.

Described from three galls; one alcoholic and two dried specimens. About the middle of August, 1892, the pill box containing the two dried galls was opened and found to contain a metallic dark green microhymenopteron with an ovipositor as long as its body. It is a minute species. Upon opening one of the dried galls, several very minute transformed hymenopterous parasites were found in the terminal portion of the cell, and a well-formed cecidomyiid pupa with very long leg sheaths found in the basal portion. As several larvae appear to inhabit the single cell in each gall, the minute parasites probably developed in the other cecidomyiid larvae leaving one untouched to transform. The minute parasites were without ovipositor and are doubtless males of the above mentioned species. The other dried gall, which was the smallest one, contained the skin of a cecidomyiid pupa and transformed female of the above microhymenopteron. This hymenopterous parasite has been determined by $\mathrm{Mr}$. Wm. H. Ashmead as Torymus sp. It is a little over I $\mathrm{mm}$. in length (\$), with nearly clear wings. Ovipositor a little over I $\mathrm{mm}$.

head of Danais archippus," and "the taxonomic value of the scales in Lepidoptera," and now appears an excellent study of "the prothorax of butterflies," by May H. Wellman.
Recent numbers of the Kansas University Quarterly have contained valuable papers on the anatomy of Lepidoptera. Vernon L. Kellogg has discussed "the sclerites of the 

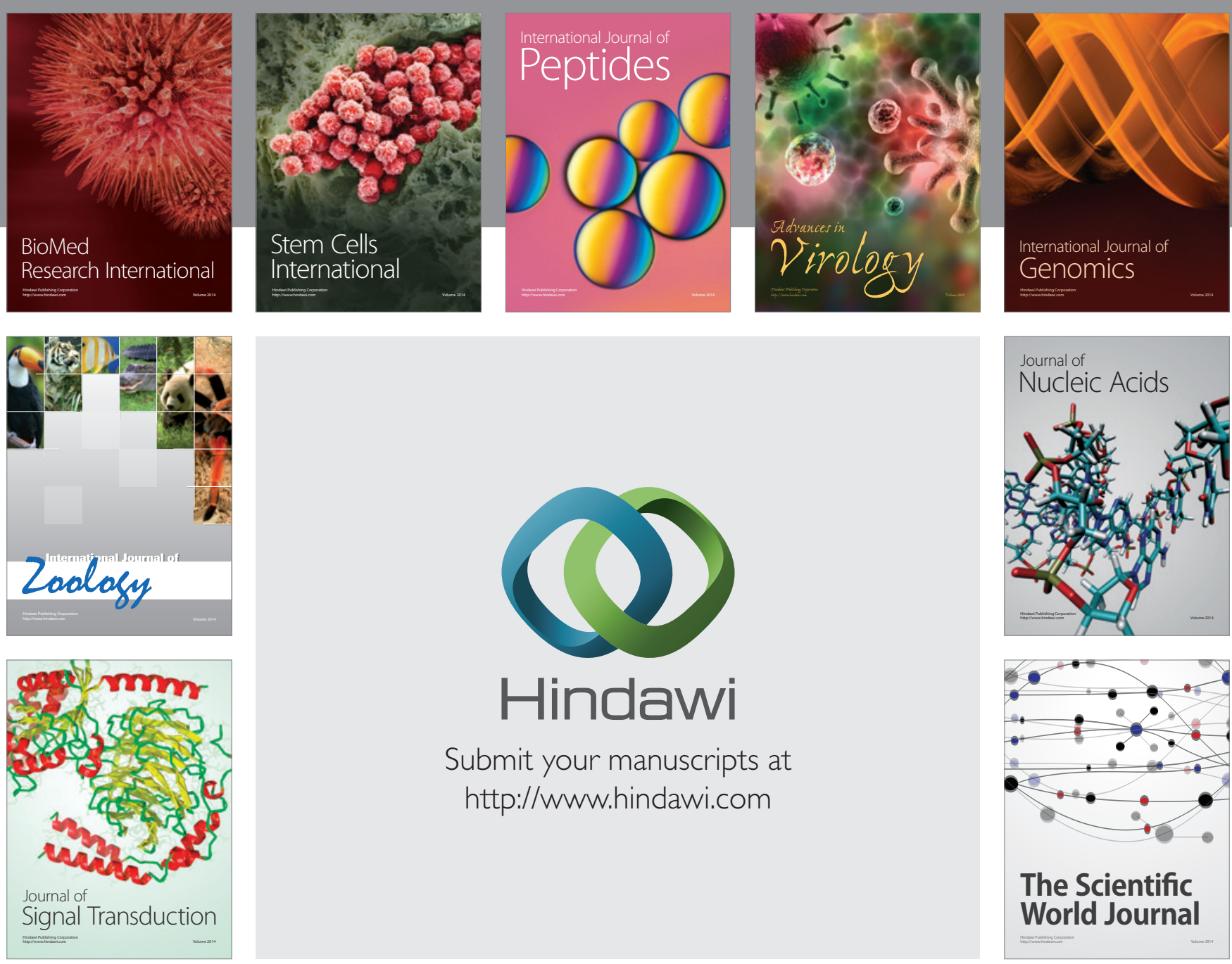

Submit your manuscripts at

http://www.hindawi.com
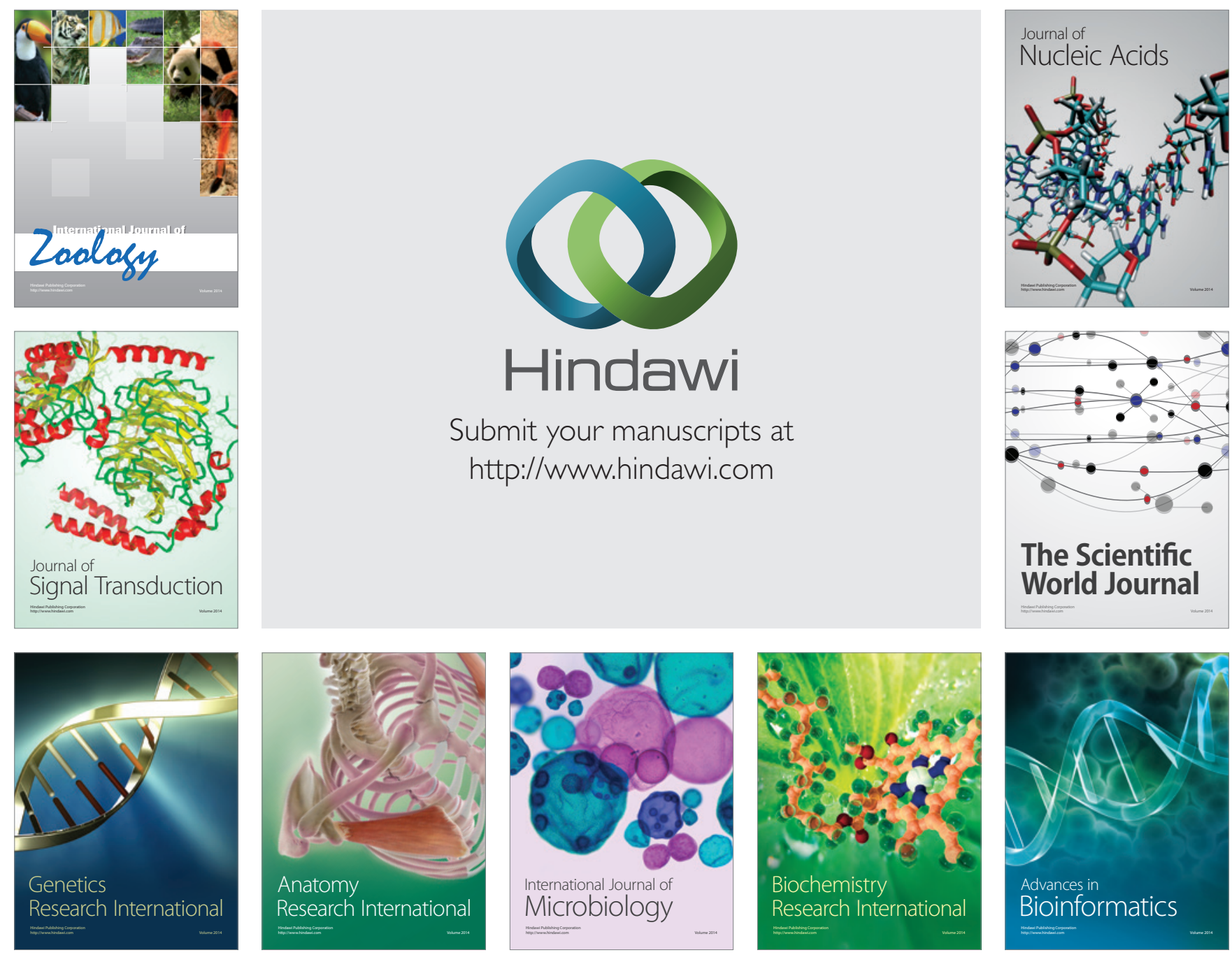

The Scientific World Journal
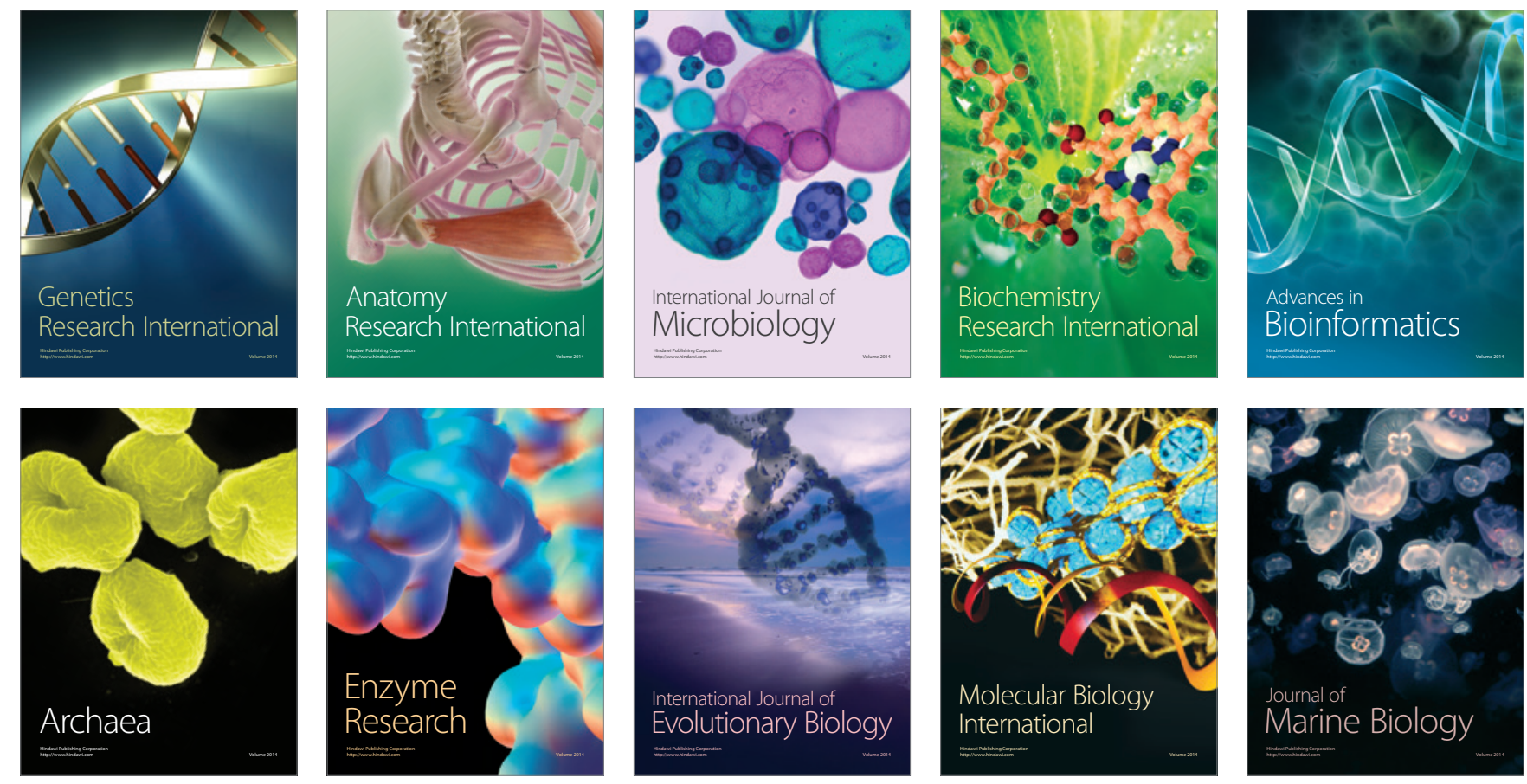